\title{
SDHA Gene Mutation
}

National Cancer Institute

\section{Source}

National Cancer Institute. SDHA Gene Mutation. NCI Thesaurus. Code C126829.

A change in the nucleotide sequence of the SDHA gene. 